\title{
POTENSI KANDUNGAN SENYAWA EKSTRAKSI DAUN PATIKAN KEBO (Euphorbia hirta L.) SEBAGAI KANDIDAT ANTIBIOTIK ALAMI
}

\author{
Zulkarnain*, Cut Muthiadin, Fatmawati Nur, St. Aisyah Sijid \\ Jurusan Biologi \\ Fakultas Sains dan Teknologi UIN Alauddin Makassar \\ Jl. Sultan Alauddin No. 63, Kabupaten Gowa, Sulawesi Selatan. 92113 \\ *E-mail: zulkarnainbio@uin-alauddin.ac.id
}

\begin{abstract}
Abstrak: Penelitian ini bertujuan untuk mengetahui potensi dari kandungan senyawa ekstraksi daun patikan kebo (Euphorbia hirta L.) sebagai antibiotik alami. Hal ini dilatarbelakangi dengan masih banyaknya kasus penyakit infeksi yang terjadi di kalangan masyarakat atas sampai bawah yang mana diantaranya adalah penyakit infeksi yang disebabkan oleh serangan bakteri, selain itu juga dengan masih banyaknya penggunaan antibiotik yang tidak sesuai baik jenis dan takarannya sehingga menyebabkan terjadinya resistensi antibiotik. Parameter penelitian ini adalah munculnya zona bening pada daerah sekitaran kertas cakram yang telah direndam dengan beberapa konsentrasi dari ekstrak daun patikan kebo di medium pertumbuhan bakteri yang sebelumnya telah diinokulasikan dengan dua perwakilan bakteri gram negatif (Escherichia coli) dan gram positif (Staphylococcus aureus). Hasil penelitian ini berdasarkan uji statistik menunjukkan bahwa pemberian ekstrak patikan kebo berpengaruh nyata dalam menghambat pertumbuhan kedua jenis bakteri tersebut, yang mana semakin tinggi konsentrasi ekstrak daun patikan kebo, maka semakin besar pula zona hambat yang terbentuk di sekitaran kertas cakram tersebut.
\end{abstract}

Kata Kunci: antibiotik, Escherichia coli, Patikan kebo, Staphylococcus aureus

\section{PENDAHULUAN}

$\mathrm{P}$ enyakit infeksi merupakan salah satu jenis penyakit yang memiliki tingkat prevalensi yang cukup tinggi di dunia. Salah satu jenis penyakit infeksi yang marak terjadi adalah penyakit infeksi oleh golongan mikroba dalam hal ini, bakteri. Diantara pengobatan yang dilakukan untuk mengobati penyakit infeksi yang diakibatkan oleh bakteri adalah dengan penggunaan antibiotik yang merupakan senyawa yang mampu menghambat pertumbuhan bahkan membunuh bakteri (Djide et al., 2008). Beberapa jenis antibiotik yang umum digunakan dalam mengobati penyakit infeksi bakteri adalah Amoksisilin yang merupakan antibiotik sintetik dan masuk dalam kategori obat generik golongan penisilin yang sangat ampuh dalam membunuh bakteri gram positif dan negatif (Maida et al., 2019). Akan tetapi penggunaan antibiotik sintetik ini dalam mengobati penyakit infeksi ditengarai mampu meningkatkan resistensi terhadap bakteri dan juga tergolong mahal, sehingga perlunya pengembangan penelitian dalam hal eksplorasi antibiotik dari bahan-bahan alami. 
Indonesia sebagai salah satu negara yang kaya akan flora dan fauna dengan tingkat biodiversitas yang sangat tinggi, dari sekian banyak flora yang ada di Indonesia terdapat sekitar 30.000 jenis yang telah berhasil diidentifikasi oleh para ahli taksonomi tumbuhan (Yovita et al., 2010). Flora tersebut telah banyak dimanfaatkan oleh masyarakat Indonesia, mulai dari flora yang dijadikan sebagai bahan makanan, tempat tinggal, hingga pengobatan alami atau tradisional (Hembing, 2008; Ngajow et al., 2013).

Potensi tanaman obat bisa dilihat dari kandungan fitokimia yang dimiliki oleh suatu tanaman. Tanaman obat merupakan tanaman atau bagian dari tanaman yang digunakan sebagai bahan obat alami atau tradisional yang kemudian dijadikan sebagai bahan baku, diantaranya adalah patikan kebo (Euphorbia hirta L.) yang dikenal dengan nama yang berbeda-beda di tiap-tiap daerah. Tanaman ini merupakan tanaman yang masuk dalam kelompok tanaman monokotil dan berada pada famili Euphorbiaceae. Dari jumlah keseluruhan Genus Euphorbia yang ada sekitar 2000 spesies di dunia adalah merupakan famili dari Euphorbiaceae, yang telah ditemukan sekitar 80 jenis di India dan terebar luas di daerah-daerah yang memiliki iklim tropis (Manjur et al., 2015). Tanaman ini telah banyak dilaporkan bermanfaat sebagai tanaman obat, diantaranya mampu mengobati beberapa penyakit, diantaranya radang, disentri, diare, asma, bronchitis (Yuda et al., 2017), bahkan juga berpotensi sebagai anti diuretik (peluruh urin) (Rattus et al., 2014).

\section{METODE PENELITIAN}

Penelitian ini merupakan penelitian kuantitatif dengan pendekatan eksperimental dengan tujuan melihat hubungan antara satu variabel dengan variabel yang lain dalam hal ini adalah pengaruh ekstrak hasil daun patikan kebo dengan beberapa konsentrasi terhadap pertumbuhan bakteri Staphylococcus aureus dan Escherichia coli. Penelitian ini dilaksanakan di Laboratorium Mikrobiologi Jurusan Biologi Fakultas Sains dan Teknologi UIN Alauddin Makassar. Penelitian ini menggunakan desain penelitian Rancangan Acak Lengkap dengan kelompok perlakuan sebagai mana yang terdapat pada Tabel 1 .

Tabel 1. Kode perlakuan

\begin{tabular}{ccl}
\hline No & Kode & \multicolumn{1}{c}{ Keterangan } \\
\hline $\mathbf{1}$ & Zsa0/Zec0 & Kontrol Negatif (Aquadest) \\
$\mathbf{2}$ & Zsa1/Zec1 & Ekstrak Patikan Kebo Konsentrasi $40 \%$ \\
$\mathbf{3}$ & Zsa2/Zec2 & Ekstrak Patikan Kebo Konsentrasi $45 \%$ \\
$\mathbf{4}$ & Zsa3/Zec3 & Ekstrak Patikan Kebo Konsentrasi $50 \%$ \\
$\mathbf{5}$ & Zsa4/Zec4 & Ekstrak Patikan Kebo Konsentrasi $55 \%$ \\
$\mathbf{6}$ & Zsa5/Zec5 & Ekstrak Patikan Kebo Konsentrasi 60\% \\
\hline
\end{tabular}

Alat yang digunakan pada penelitian ini adalah destilator, blender, cawan petri, inkobator, Laminar air flow, neraca analitik, tabung reaksi, oven, gelas kimia, pembakar sprirtus, labu erlenmeyer, vortex, bunsen, gelas ukur, jangka sorong, spoit, mikro pipet, ose bulat. Bahan yang digunakan pada penelitian ini adalah daun patikan kebo (Euphorbia hirta L.), isolat bakteri Staphylococcus aureus dan Escherichia coli, Medium Nutrient Agar, Aquadest, pelarut etanol 96\%, dan alkohol 70\%, alumunium foil, dan kertas cakram.

Pelaksanaan penelitian terdiri dari beberapa tahapan yaitu:

1. Persiapan

Tahapan ini meliputi pembuatan medium Nutrient Agar (NA) dengan komposisi 
ekstrak beef, pepton, bacto agar, dan aquadest. Semua bahan tersebut dicampur dengan tarakan yang sesuai kemudian disterilisasi menggunakan autoklaf dengan suhu $120^{\circ} \mathrm{C}$ selama 15 menit. Selain itu yang masuk dalam tahapan persiapan adalah sterilisasi seluruh intrumentasi yang akan digunakan.

2. Pelaksanaan

Tahapan ini meliputi pembuatan ekstraksi daun patikan kebo dengan cara daun yang telah disiapkan selanjutnya dibersihkan kemudian dikering-anginkan kurang lebih 1 pekan selanjutnya diblender lalu diambil sebanyak 200 gram kemudian dilanjutkan pada tahapan maserasi selama 24 jam pada etanol $96 \%$ sebanyak $800 \mathrm{ml}$, kemudian selanjutnya dilakukan penyaringan untuk memisahkan bagian ampas dan larutan. Kemudian dilakukan proses destilasi menggunakan destilator selama kurang lebih 2 jam sehingga pada akhirnya akan dihasilkan ekstraksi daun patikan kebo yang kemudian akan digunakan sesuai dengan konsentrasi masing-masing untuk dilakukan pengujian pada mikroba uji. Tahapan lainnya adalah peremajaan mikroba uji dan pembuatan suspensi mikroba. Kemudian tahapan inti dari pelaksanaan penelitian ini adalah pengujian kemampuan kandungan senyawa ekstraksi daun patikan kebo pada mikroba uji yaitu masing-masing mikroba uji dicampurkan pada medium Nutrient Agar (NA) yang telah padat, kemudian dilakukan perendaman kertas cakram pada beberapa konsentrasi ekstrak patikan kebo, setelah itu diletakkan pada permukaan medium NA pada cawan petri dan diikubasi selama 24 jam, setelah itu mengukur diameter zona bening yang terbentuk pada daerah sekitaran kertas cakram. Metode yang digunakan adalah metode disk-diffusion (Kirby \& baur) yaitu dengan menggunakan cakram yang telah berisi antimikroba yang diletakkan pada media agar padat yang telah diinokulasikan mikroba uji kemudian melihat area bening/jernih sebagai indikator adanya penghambatan pertumbuhan mikroba oleh antimikroba yang selanjutnya diukur diameter area bening/jernihnya (zona hambat) (Pratiwi, 2008).

\section{HASIL DAN PEMBAHASAN}

Hasil penelitian menunjukkan adanya pengaruh ekstrak patikan kebo (Euphorbia hirta L) dalam menghambat pertumbuhan bakteri Staphylococcus aureus sebagaimana yang ditunjukkan pada Tabel 2 .

Tabel 2. Rata-rata diameter zona bening penghambatan pertumbuhan bakteri Staphylococcus aureus oleh ekstrak daun patikan kebo dengan masa inkubasi 24 jam

\begin{tabular}{|c|c|c|c|c|c|}
\hline Perlakuan & & Ulangan & & Jumlah & $\begin{array}{c}\text { Rerata Diameter } \\
\text { Zona Bening } \\
(\mathbf{m m})\end{array}$ \\
\hline Zsa 0 (kontrol) & 0 & 0 & 0 & 0 & $0,00^{\mathrm{a}}$ \\
\hline Zsa $1(40 \%)$ & 3,2 & 3 & 2,5 & 8,7 & $2,90^{\mathrm{b}}$ \\
\hline Zsa $2(45 \%)$ & 4,2 & 3,2 & 3,3 & 10,7 & $3,56^{\mathrm{bc}}$ \\
\hline Zsa $3(50 \%)$ & 5,0 & 3,5 & 3,5 & 12 & $4,00^{\mathrm{cd}}$ \\
\hline Zsa $4(55 \%)$ & 6,5 & 4,7 & 4,6 & 15,8 & $5,26^{\mathrm{de}}$ \\
\hline Zsa $5(60 \%)$ & 7,0 & 4,8 & 4,7 & 16,5 & $5,5^{\mathrm{e}}$ \\
\hline Jumlah & 25,9 & 19,2 & 18,6 & 63,7 & 21,22 \\
\hline
\end{tabular}

BNT $\alpha 0,05=1,50$

Begitu pula pada bakteri Escherichia coli, terlihat kemampuan kandungan yang dimiliki oleh ekstrak daun patikan kebo kebo (Euphorbia hirta L) dalam menghambat pertumbuhannya sebagaimana yang ditunjukkan pada Tabel 3. 
Tabel 3. Rata-rata diameter zona bening penghambatan pertumbuhan bakteri Escherichia coli oleh ekstrak daun patikan kebo dengan masa inkubasi 24 jam

\begin{tabular}{lccccc}
\hline \multicolumn{1}{c}{ Perlakuan } & Ulangan & & Jumlah & $\begin{array}{c}\text { Rerata diameter } \\
\text { Zona bening (mm) }\end{array}$ \\
\hline Zec 0 (kontrol) & 0 & 0 & 0 & 0 & $0,00^{\mathrm{a}}$ \\
Zec 1 (40\%) & 3,3 & 3,1 & 2,7 & 9,1 & $2,90^{\mathrm{b}}$ \\
Zec 2 (45\%) & 3,6 & 3,2 & 3,2 & 9,5 & $3,56^{\mathrm{bc}}$ \\
Zec 3 (50\%) & 4 & 3,5 & 3,7 & 11,2 & $4,00^{\mathrm{cd}}$ \\
Zec 4 (55\%) & 4,2 & 4,5 & 4,6 & 13,3 & $5,26^{\text {de }}$ \\
Zec 5 (60\%) & 4,5 & 5,1 & 5 & 14,6 & $5,5^{\mathrm{e}}$ \\
Jumlah & 19,6 & 19,4 & 15,5 & 57,7 & 21,22 \\
\hline
\end{tabular}

Berdasarkan hasil yang diperoleh sebagaimana yang terlihat pada Tabel 2 dan Tabel 3 diketahui bahwa ekstrak daun patikan kebo mampu menghambat pertumbuhan mikroba uji yaitu Staphylococcus aureus dan Escherichia coli, hal ini dapat diketahui dari terbentuknya zona bening (hambat) di daerah sekitaran kertas cakram dengan konsentrasi yang berbeda-beda. Terlihat bahwa ada kenaikan jumlah rata-rata diameter zona bening yang terbentuk berdasarkan kenaikan konsentrasi ekstrak patikan kebo. Kriteria yang digunakan dalam menentukan kekuatan antibakteri salah satunya adalah dengan melihat diameter zona hambat yang terbentuk, zona hambat 15-20 mm adalah daya hambat kuat, 10-14 $\mathrm{mm}$ adalah daya hambat sedang, dan 0-9 adalah daya hambat lemah (Nazri et al., 2011). Sehingga dapat disimpulkan bahwa ekstrak patikan kebo memiliki potensi sebagai antibiotik yang rendah.

Data hasil pengamatan menunjukkan rata-rata bahwa Staphylococcus aureus menghasilkan diameter zona hambat lebih besar dibandingkan dengan Escherichia coli. Hal ini disebabkan karena adanya perbedaan struktur dinding sel pada bakteri gram positif (Stahylococcus aureus) dengan bakteri Gram negatif (Escherichia coli). Struktur dinding sel bakteri Gram negatif lebih kompleks dibandingkan struktur dinding sel bakteri gram positif. Bakteri Gram negatif memiliki dinding sel yang terdiri dari 3 lapisan yaitu, lapisan luar, lapisan tengah dan lapisan dalam. Sedangkan bakteri gram positif hanya mempunyai lapisan tunggal pada dinding selnya (Pelczar et al., 2008).

Struktur dinding sel bakteri Gram negatif yang relatif kompleks tersebut menyebabkan antibiotik lebih sukar masuk ke dalam sel dan menemukan sasaran untuk bekerja. Untuk menunjukkan kerja antibiotik pada bakteri Gram negatif, antibiotik terlebih dahulu harus mampu menembus membran terluar dari selubung bakteri secara difusi pasif melalui saluran yang terbentuk oleh pori protein. Setelah itu, antibiotik akan masuk melalui dinding sel melewati ruang periplasma dan mencapai sasaran, yaitu enzim serin protease yang terdapat pada membran terdalam (sitoplasma). Enzim inilah yang bertanggung jawab terhadap biosintesis dinding sel. Sehingga diperoleh hasil bahwa bakteri gram positif memiliki diameter yang lebih besar dari bakteri gram positif

Ada beberapa faktor yang dapat mempengaruhi kerja zat antimikroba, diantaranya adalah: umur bakteri, konsentrasi zat antimikroba, suhu, kandungan bahan antimikroba, dan sebagainya. Dimana kecepatan populasi mikroba mengalami kematian erat hubungannya dengan umur mikroba. Pada umumnya mikroba yang lebih muda daya tahannya lebih rendah dibandingkan dengan bakteri yang lebih tua (fase stasioner). Kemampuan suatu bahan dalam menghambat atau membentuk mikroba tergantung pada tinggi rendahnya konsentrasi dan bahan antimikroba. Pada umumnya, kecepatan kematian mikroba berhubungan secara langsung dengan konsentrasi antimikroba. Ini berarti semakin tinggi konsentrasi antimikroba yang digunakan, semakin cepat mikroba 
terbunuh. Selain itu cara kerja antimikroba adalah dengan merusak dinding sel mikroba, menyebabkan perubahan permeabilitas apada sel mikroba, mengakibatkan terjadinya perubahan pada molekul protein dan juga asam nukleat mikroba, menghambat kerja enzim, dan sintesis asam nukleat protein mikroba (Pelczar et al., 2008).

Terbentuknya zona bening (zona hambat) di sekeliling paper disk ini disebabkan oleh karena adanya zat-zat yang bersifat antimikroba yang terkandung dalam daun Patikan kebo (Euphorbia hirta L.), sebagaimana yang telah diketahui bahwa patikan kebo mengandung beberapa unsur kimia diantaranya adalah diantaranya alkaloid, tanin, senyawa folifenol, flavonoid, terpen, dan asam lanolat.

Tanin merupakan salah satu senyawa yang mempunyai aktivitas sebagai antimikroba terhadap Escherichia coli, Staphylococcus aureus, dan Streptococcus faecalis. Tanin dalam konsentrasi rendah mampu menghambat pertumbuhan bakteri, sedangkan pada konsentrasi tinggi tanin bekerja sebagai antibakteri dengan mengkoagulasikan protoplasma bakteri karena terbentuk ikatan yang stabil dengan protein bakteri. Secara garis besar mekanisme yang diperkirakan adalah sebagai berikut: toksisitas tanin dapat merusak membran sel bakteri, senyawa tanin dapat menginduksi pembentukan kompleks senyawa ikatan terhadap enzim atau subtrat mikroba dan pembentukan suatu kompleks ikatan tanin terhadap ion logam yang dapat menambah daya toksisitas tanin itu sendiri. Efek antibakteri tanin antara lain melalui: reaksi dengan membran sel, inaktivasi enzim, dan destruksi atau inaktivasi fungsi materi genetik (Ajizah, 2004).

Selain itu senyawa lain yang bekerja adalah Senyawa flavonoid dan fenol yang mempunyai kecenderungan untuk mengikat protein bakteri sehingga menghambat aktivitas enzim yang pada akhirnya mengganggu proses metabolisme bakteri. Secara umum senyawa fenolik memiliki potensi sebagai bakterisid, antiseptik, dan juga antibiotik (Pengelly, 2006). Flavonoid merupakan senyawa fenol yang bersifat koagulator protein. Fenol ini juga berperan daam mendaturasi protein pada sel bakteri yang pada akhirnya akan menyebabkan struktur proteinnya rusak oleh karena adanya ikatan hidrogen antara protein dari sel bakteri dan senyawa fenol (Carolia et al., 2016). Selain itu juga flavonoid memiliki kemampuan sebagai antimikroba dengan cara menyebabkan lisis pada sel bakteri serta menyebabakan gangguan pada permeabilitas dari membran (Cyrille et al., 2018). Rusaknya membran sel bakteri oleh karena adanya ikatan atau reaksi yang terjadi dengan senyawa fenol yang juga mengakibatkan makromolekul beserta ionion yang ada pada sel bakteri sehingga terjadilah kerusakan sel hingga sampai pada tahapan kematian sel (Hafsari et al., 2015).

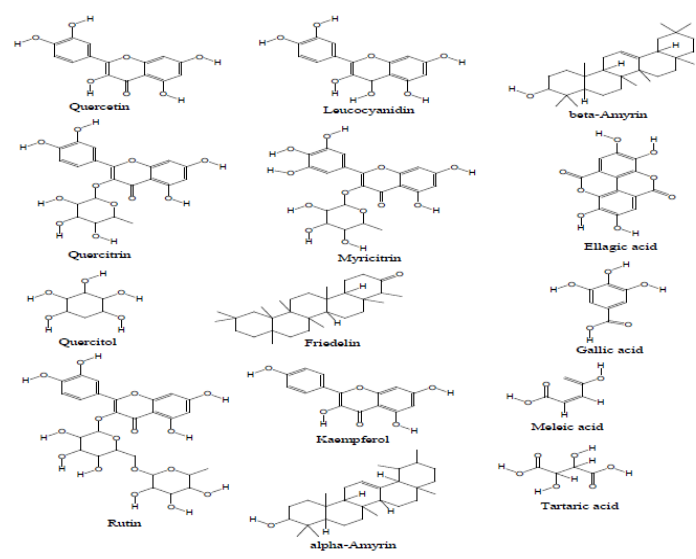

Gambar 1. Struktur Senyawa utama Flavonoid dari Patikan Kebo (Euphorbia hirta L.) (Linfang et al., 2012) 
Selanjutnya adalah senyawa alkaloid yang memiliki kemampuan sebagai antibakteri (Jati et al., 2019). Mekanisme kerja dari senyawa alkaloid pada sel bakteri adalah dengan mengacaukan komponen penyusun peptidoglikan yang ada pada dinding sel bakteri, yang pada akhirnya akan membuat lapisan dinding sel tidak terbentuk secara sempurna hingga akan menyebabkan kematian sel bakteri tersebut (Amalia et al., 2018).

\section{KESIMPULAN}

Berdasarkan hasil penelitian yang diperoleh dan diuraikan, dapat disimpulkan bahwa daun patikan kebo (Euphorbia hirta L.) memiliki potensi sebagai kandidat antibiotik alami dengan beberapa kandungan senyawa aktif yang terdapat di dalamnya berdasarkan pengujian ekstraksi beberapa konsentrasi yang diujikan pada 2 jenis bakteri yang masing-masing mewakili bakteri gram positif dan bakteri gram negatif yaitu Staphylococcus aureus dan Escherichia coli.

\section{DAFTAR PUSTAKA}

Ajizah, A. (2004). Sensitivitas Salmonella typhimurium terhadap Ekstrak Daun Psidium Guajava L. Bioscientiae, 1(1), 31-38.

Amalia, R., Marfu'ah, N., \& Amal, S. (2018). Aktivitas Antibakteri Kayu Siwak (Salvadora persica) Fraksi Eter terhadap Bakteri (Staphylococcus aureus) secara In Vitro. Pharmasipha, 2(1), 1-6.

Carolia, N., \& Noventi, W. (2016). Potensi Ekstrak daun Sirih Hijau (Piper betle L.) sebagai Alternatif Terapi Acne vulgaris. Medical Journal of Lampung University, 5(1), 140-145.

Cyrille, N. T., Tamokou, J.-D., Ekom, S. E., \& Voutquenne-Nazabadioko, D. N. \& L. (2018). Antimicrobial activities of flavonoid glycosides from Graptophyllum grandulosum and their mechanism of antibacterial action. BMC Complementary Medicine and Therapies, 18(252), 1-10. doi: https://doi.org/10.1186/s12906-018-2321-7.

Djide, M. N., \& Sartini. (2008). Dasar-dasar Mikrobiologi Farmasi. Makassar: Universitas Hasanuddin Press.

Hafsari, A. rahmi, Cahyanto, T., Sujarwo, T., \& Lestari, R.I. (2015). Uji Aktivitas Antibakteri Ekstrak Daun Beluntas (Pluchea indica L.) terhadap Propionibacterium acnes Penyebab Jerawat. Jurnal Istek, 9(1), 141-161.

Hembing, W. K. (2008). Ramuan Lengkap Herbal Taklukkan Penyakit. Jakarta: Pustaka Bunda.

Jati, N. K., Prasetya, A. T., \& Mursiti, S. (2019). Isolasi, Identifikasi, dan Uji Aktivitas Antibakteri Senyawa Alkaloid Pada Daun Pepaya. Jurnal FMIPA, 42(1), 1-6.

Linfang, H., C, S., \& Y., M. (2012). A Review on Its Ethnopharmacology, Phytochemistry and Pharmacology. Journal of Medicinal Plants Research, 6(39), 5176-5185.

Maida, S., \& Lestari, K. A. P. (2019). Aktivitas Antibakteri Amoksisilin terhadap Bakteri Gram Positif dan Gram Negatif. Jurnal Pijar MIPA, 14(3), 189-191. doi: 10.29303/jpm.1029.

Manjur, A., Begum, R., Abuzer, A., Krishna, K., Vindhu, A., Manju, S., \& Showkat, R. (2015). Inhibition of a-Glucosidae by New Prenylated Flavonoids from Euphorbia hirta L. Herb. Journal of Ethnopharmocology, 176, 1-8.

Nazri, N., Adnan, A., Ahmat, A., SAS, M., \& SAS, R. (2011). in Vitro Antibacterial and Radical Scavenging Activities of Malaysian Table Salad. African Journal of Biotechnology, 10(30), 57285735.

Ngajow, M., Abidjulu, J., \& Kamu, V.S. (2013). Antibacterial Effect of Matoa Stem (Pometia pinnata) peels Extract to Staphylococcus aureus Bacteria In Vitro. Jurnal MIPA UNSRAT, 2(2), 128-132. doi: https://doi.org/10.35799/jm.2.2.2013.3121

Pelczar, M. J., \& Chans, E. C. . (2008). Dasar-dasar Mikrobiologi (1st ed.). Jakarta: UI Press.

Pengelly, A. (2006). The Constituents of Medical Plants: an Introduction to the Chemistry and Theraputics of Herbal Medicines (2nd ed.). Australia: Allen Uwin.

Pratiwi. (2008). Mikribiologi Farmasi. Jakarta: Erlangga.

Rattus, W., Lingga, I. S., Citraningtyas, G., \& Lolo, A. (2014). Uji Efek Ekstrak Etanol Patikan Kebo (Euphorbia hirta Linn.) sebagai Diuretik Pada Tikus Putih Jantan Galur Wistar (Rattus norvegicus Sp.). Pharmacon, 3(3), 287-293. doi: 10.35799/pha.3.2014.5401.

Yovita, \& Yoanna. (2010). Tanaman Obat Plus Pengobatan. Jakarta: Setia Kawan.

Yuda, P.E.S.K., Cahyaningsih, E., \& Winariyanthi, N.P.Y. (2017). Skrining Fitokimia dan Analisis 
196 Jurnal Teknosains, Volume 15, Nomor 2, Mei-Agustus 2021, hlm. 190-196

Kromatografi Lapis tipis Ekstrak Tanaman patikan Kebo (Euphorbia hirta L.). Jurnal Ilmiah Medicamento, 3(2), 61-70. doi: 10.36733/medicamento.v3i2.891. 